\title{
STUDY ON IMPROVING RAIL ENERGY EFFICIENCY (E2): BEST PRACTICES AND STRATEGIES
}

\author{
Dr. Aviva Brecher \\ USDOT \\ Volpe National Transportation Center \\ Energy Analysis and Sustainability \\ Cambridge, MA, USA
}

\author{
Melissa Shurland \\ USDOT \\ Federal Railroad Administration \\ Washington, DC, USA
}

\begin{abstract}
A recent Volpe Center report [1] for the Federal Railroad Administration's (FRA) Rail Energy, Environment, and Engine (E3) Technology research and development program reviewed rail industry best practices (BPs) and strategies for improving energy efficiency (E2) and environmental sustainability. The review included examples of and opportunities for adoption of international transferrable BPs, and US technologies for equipment, operations and logistics software tools that have measurably improved E2 performance for passenger and freight railroads. Drivers providing renewed impetus for rail industry E2 advances include environmental compliance requirements with US Environmental Protection Agency (EPA) locomotive emission standards, US Department of Transportation Congestion Mitigation and Air Quality improvement program grants, state, regional and urban clean diesel campaigns, as well as the FRA National Rail Plan, and High-Speed Intercity Passenger Rail (HSIPR) initiatives. The report presented comparative rail system energy efficiency data and trends relative to competing modes, illustrated the benefits of energy- efficient technologies, and of alternative fuels use. Based on a comprehensive literature review and on experts' inputs, the report highlighted models of corporate rail sustainability plans and system-wide BPs and success stories. Available rail equipment and operational practices proven to improve $\mathrm{E} 2$ with environmental and economic benefits for all rail industry segments were illustrated. Findings and recommendations for further improving rail E2 and sustainability were tailored to the specific needs and goals of intercity and commuter passenger rail, and freight railroads (Class I-III). Key opportunities highlighted included: public-private partnerships (P3) with Federal agencies (FRA, EPA/SmartWay) for joint research,
\end{abstract}

development test and evaluation (RDT\&E)on advanced equipment (electric and hybrid, or dual fuel locomotives), or alternative fuels (biodiesel, CNG/LNG, Fuel cells/Hydrogen); participation in international rail organizations (UIC) and trade associations (AAR, AREMA, APTA, AASHTO), and partnering with regional and State environmental protection agencies for cross-enterprise E2 and sustainability improvements.

\section{INTRODUCTION}

Although the primary FRA mission is to preserve, enforce, and enhance rail safety, the E3 R\&D program also supports the DOT strategic goals of livable communities, economic competitiveness, and environmental sustainability and assists the rail industry. The purpose of the Volpe Center study- sponsored by the FRA E3 research program- was to identify successful rail industry best practices (BPs) and strategies for improving system-wide energy efficiency (E2), with associated environmental benefits. Although the rail sector consumes only $1.82 \%$ of the total US transportation energy consumed per year in the US, versus $79 \%$ consumed by road vehicles in 2014, railroads continue to reduce their fuel and energy consumption for both economic and environmental benefits (Figure 1). Rapid industry progress on E2/E3 is continuing, and ongoing related studies by Transportation Research Board (TRB) National Corporative Rail Research Program (NCRRP) and by Connecticut Department of Transportation/CT Academies of Science and Engineering [2,3] will soon be completed. Recent rail industry E2 improvements were spurred by FRA's National Rail Plan, the High-Speed Intercity Passenger Rail (HSIPR) initiative, compliance with 
EPA locomotive emission regulations and state and local environmental constraints.

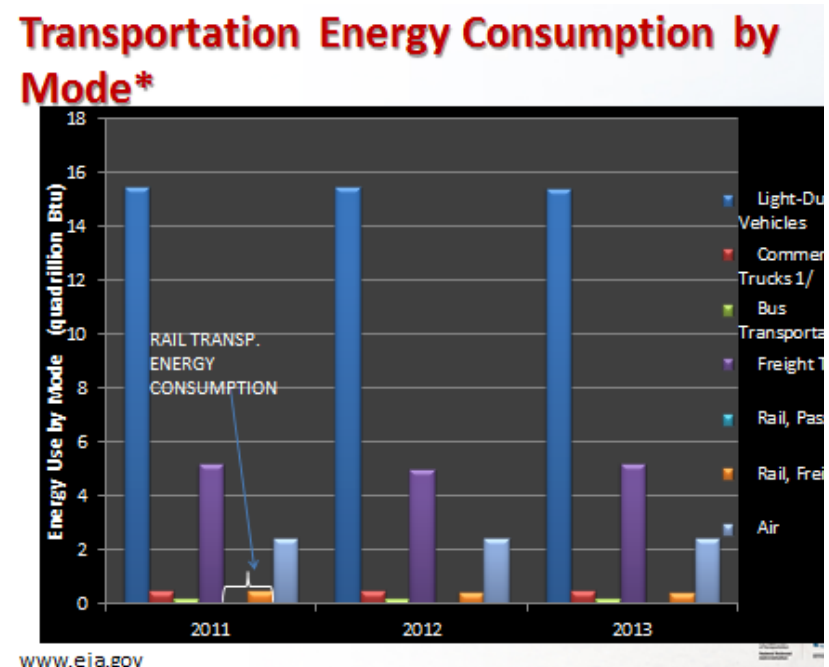

Figure 1: Modal shares of transportation energy consumption (EIA data)

The report summarized relevant E2 trends and findings, based on a comprehensive review of literature, complemented by inputs from rail industry sustainability managers. The study focused on illustrating- for all rail industry segments- the E2/E3 benefits of adopting new Tier 3 or 4 compliant locomotives (diesel, hybrid, electric, or dual fuel), the use of retrofit kits for idle reduction and emission abatement, experience with emerging alternative fuels, and operational optimization tools that reduce fuel consumption. Progress in E2 for all segments of the rail industry, and leadership in using emerging technologies and alternative fuels was highlighted.

International lessons learned transferrable to the US rail operating environment were discussed, as well as emerging technology options, equipment upgrades, and system-wide operational and environmental sustainability advances and metrics. E2 performance metrics used by UIC, and its multiyear initiatives like the comprehensive Railenergy (NRG) R\&D project [4] could serve as a model to assess and optimize E2 for the US rail system at both technical and operational levels. E2 metrics must be customized to the US operating environment since most passenger and freight rail operations share tracks in the US, in contrast to high speed rail (HSR) in Europe and Japan, which operate on dedicated electrified ROW. HSR technologies with high E2 and recovery of braking energy losses are relevant to planned US HSR deployment. There are inherently different E2 metrics for fuel burned for freight rail (ton-mi per gallon of fuel consumed), vs. passenger rail (for which energy intensity is commonly expressed in Btu/passenger-mile reflecting loading ratios, or per seat-mile reflecting capacity). For instance, Amtrak energy consumption on the NEC is 2,435 Btus/passenger mi, but varies with the loading factor (typically 60-80\% on NEC).
Examples of rail system-wide BPs, such as corporate sustainability plans and annual reports, rail equipment and fleet upgrades of intercity and commuter passenger rail, or freight (Class I-III) were offered to illustrate and quantify E2 performance improvements with associated environmental and economic benefits, and to inspire industry-wide adoption.

\section{EQUIPMENT TECHNOLOGIES AND TOOLS FOR TIER 4 ENVIRONMENTAL COMPLIANCE}

The report illustrated with examples and case studies successful strategies and best practices to improve E2 across all rail industry segments, including:

- Newer, and more efficient freight line-hauls and switcher locomotives

- Adoption of advanced technologies as retrofits (retrofit kits to overhaul legacy fleet locomotives)

- Emission reduction with idle control technologies for diesel-powered switcher and line-haul locomotives (Automatic Engine Stop Start- AESS and Auxiliary Power units- APUs that could be fuel cells)

- Use of on-board and wayside rechargeable energy storage system (RESS) technologies using flywheels, batteries, or capacitors for electrified passenger intercity and commuter rail

- $\quad$ Replacing push-pull passenger locomotives with Electric Multiple Units (EMU), efficient Diesel Multiple Units (DMUs) and/or dual fuel locomotives, combined with bilevel (double decker coaches $\mathrm{s}$

- Use of distributed power unis for long freight trains can save $4-6 \%$ of fuel, while reducing wheel and track wear

- Use of regenerative braking on electrified territory (EMUs) for

- Deployment of GenSets switcher locomotives for railyards in or near non-attainment metro areas

- Emerging alternative/renewable fuels (biodiesel, natural gas, hydrogen fuel cell)

- Improved maintenance (e.g., top-of-the wheel lubrication) and operating practices

- Communications and monitoring tools consisting of GPSenabled communications for dispatch and engineer performance management. Examples are: LEADER-the Locomotive Engineer Assist Display and Event Recorder (LEADER), which helped the Norfolk Southern (NS) Railroad fleet achieve 25 percent fuel savings; and the Event Recorder Automated Download (ERAD) used by CSX to provide feedback to locomotive engineers on how to improve fuel efficiency, performance, and operational safety. The scorecard produced by ERAD tracks operational habits (starting/stopping/braking) to optimize performance, and thus improves E2.

Successfully deployed E2 rail equipment discussed in the report include:

- GenSets locomotives from several manufacturers are commonly deployed in rail yards to comply with Tier 3 and 3+ EPA emission standards; some have multiple small 
engines and generators that can be activated for traction power on demand.

- Ultra-clean diesel electric locomotives and repower kits available for fleet renewal or upgrades.

- Diesel Multiple Units (DMUs) in distributed power configurations, when combined with idle reduction devices and with energy use monitoring capabilities (like LEADER) can considerably reduce fuel consumption.

- EMUs on electrified track and hybrid electric and dual power locomotives offer E2 advantages in mixed-use territory, while a short-haul battery electric locomotive was tested and is being improved for long haul.

- Software tools for streamlined operations also improve asset management, logistics, and E2. Rail operations on shared track using GPS and Positive Train Control (PTC) for safety and asset management also improve E2.

- $\quad$ Alternative fuels being explored by most Class I railroads promise equal or better E2, as well as environmental sustainability (biodiesel, hydrogen fuel cells, CNG, and LNG).

\section{EXAMPLES OF SUCCESSFUL FREIGHT RAIL E2 IMPROVEMENTS}

The report success stories in improving E2 highlighted several specific equipment upgrades, combined with operations and logistics optimization tools were illustrated with examples for all industry segments freight (Class I-III) and passenger (intercity, HSIPR and commuter) railroads. In 2015, the railroads are preparing to meet the stringent Tier 4 EPA locomotive emission standards for newly manufactured equipment, building on prior successful strategies. Equipment suppliers have been developing and testing cleaner and more energy efficient locomotives for fleet upgrade and renewal [5]. Several AAR white papers summarized the freight railroads fuel efficiency and associated environmental gains [6] reaching an average of 473 ton-mi per gallon of fuel burned (a 101\% gain since 1980), and the environmental benefits of shifting freight to rail from trucks [7].

A notable advance is the large scale deployment of clean and efficient 4 or 6 axle (AC or DC) Genset switcher locomotives. The Class I freight railroads have gradually replaced the powerful diesel locomotive engine in yard switching operations with fuel-efficient Genset switcher locomotives. GenSets are particularly useful for maintenance "switching activities" in and around railyards near already noisy and congested metropolitan areas, where the locomotive often idle. GenSets are equipped with a diesel particulate filter (DPF) to reduce PM emissions. Under a State Rail Emissions Reduction Program, the California Air Resources Board (CARB) and railroads entered a statewide railyard emissions abatement agreement in 2005 with Union Pacific Railroad (UPRR)and Burlington Northern Santa Fe (BNSF) [8] committing them to deploy GenSets and idle reduction systems for railyard switch locomotive fleets and for line haul locomotives operating intra-state. GenSets were proven to achieve 20-40 percent fuel savings compared with conventional switchers. However, new GenSets may be up to six times more expensive, and may be less reliable than diesel counterparts, so retrofits during repowering of aging locomotives are more affordable. GenSets have multiple (2-4) smaller off-road diesel engines to provide scalable power on demand, using heavy-duty truck and off-road vehicles diesel engines, which comply with Tier 3 or $3+$ EPA emission standards, and also use LED lighting for better E2. One or more engines shut down automatically, or enter a sleep mode if motive power is not needed within a certain predetermined time interval. For instance, the National Railway Equipment Company (NREC) GenSets have up to 3 engines of $700 \mathrm{hp}$ $(522 \mathrm{~kW})$, in 1,2 , or 3 engine models. This NREC NViroMotive $^{\mathrm{TM}}$ road Genset switcher was certified as an ultralow emissions locomotive (ULEL) by CARB in California and by the Texas Emissions Reduction Plan (TERP) program. They are used by CSX and UPRR in yards located in sensitive or non-attainment areas in California, Texas, Indiana, New York, Michigan, and Illinois. NREC has been retrofitting the entire CSX switcher fleet (Figure 2).

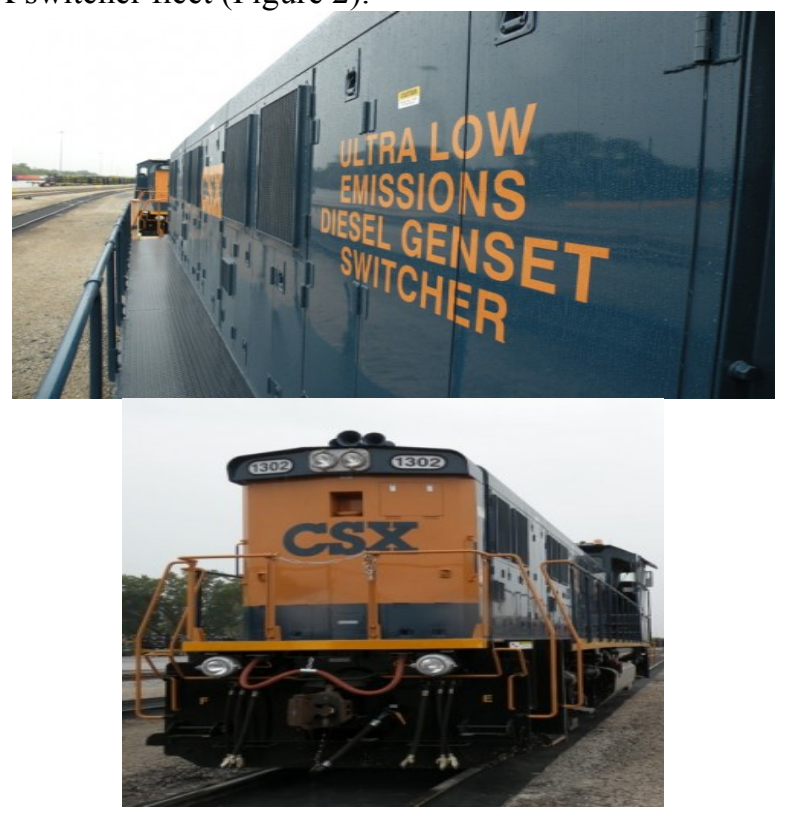

Figure 2. CSX New Diesel Genset Switcher Locomotives Operating in Chicago, California, New York, and Indiana Railyards [9]

172 UP Genset diesel switchers were certified as Tier 3 UltraLow Emission Locomotives (ULEL), and GenSets can also use alternative fuels, or come in hybrid or electric varieties. The RailPower GreenGoat diesel hybrid switcher and the GE Evolution hybrid 2010 have demonstrated additional clean technology options.

Also notable is the development and introduction in 2012 of the clean (Tier 4, ready for 2015 EPA mandates) heavy-haul GE Evolution series hybrid electric locomotive, capable of moving 1 ton of freight on 1 gallon diesel over $500 \mathrm{mi}$ [10]. The GE Evolution ES44AC locomotives purchased by Class I railroads 
reduce fuel use by $17 \%$ and emissions by $70 \%$ compared to existing DC locomotives.

\section{EXAMPLES OF INTERCITY AND COMMUTER PASSENGER RAIL E2 BEST PRACTICES}

The report illustrated numerous BPs that achieved system-wide E2 improvements implemented by Amtrak. Annual postings on energy efficiency and environmental performance include:

- "Travel Green with Amtrak" [11]

- "Going Green on Acela," a rail carbon footprint calculator for passengers, and its ClimateCounts.org scorecard.

Measures implemented to reduce fuel usage by 1 percent a year by 2015 , include:

- Installing regenerative braking in 80 percent of Northeast Corridor (NEC) locomotives and other electrified territory, to recover and reuse 8 percent of power consumed;

- Aerodynamic improvements of rolling stock;

- Installing locomotive anti-idling retrofits, such as automatic stop-start technologies, reducing locomotives diesel engine idling by shut-down within 1 hour of arrival and departure, and using $480 \mathrm{~V}$ ground power at layovers for HVAC and lighting;

- Implementing simulator training of locomotive engineers to help conserve fuel;

- Increasing the use of dynamic braking (which uses electric traction motors to provide resistance to rotating wheel axles in diesel-electric locomotives), rather than braking with power applied;

- Demonstrating the benefits of Trip Optimizer software and cruise control locomotive technologies; Upgrading fuel management systems for deliveries and consumption tracking;

- Increasing seat miles/kW-hour for electric traction power, while reducing electricity consumption for stations and facilities;

- Conducting annual environmental compliance audits and reporting GHG inventories;

- $\quad$ Seeking grant support from Federal and State agencies to replace aging switcher locomotive fleet in rail-yards with GenSets, as done in California, Illinois, New York, Virginia, Maryland, and District of Columbia;

- $\quad$ Seeking equipment upgrades for E2 and E3: a 2010 order of 70 new Siemens Amtrak Cities Sprinter ACS-64 electric locomotives (Figure 2) and America Recovery and Reinvestment Act funded upgrades in power and propulsion substations and infrastructure on the Northeast Corridor.

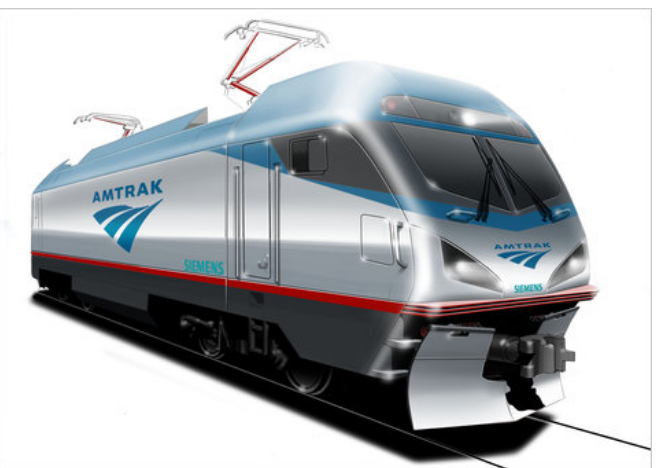

Figure 3. Amtrak Cities Sprinter can travel at $125 \mathrm{mph}(201 \mathrm{~km} / \mathrm{h})$ [12]

Among the commuter rail BPs highlighted in the report are:

- The adoption of new dual power electro-diesel locomotives that can operate efficiently on both electrified and dark territory. In 2008 New Jersey Transit ordered, and in 2011 started to deploy 26 dual powered Bombardier ALP-45DP locomotives, equipped with pantographs as a standard AC electric locomotive, and two 2,000 horsepower V-12 engines and a fuel tank to operate beyond electrified territory without changing trains (Figure 4). Although heavier than electric counterparts, the DP locomotives are more fuel efficient, quieter and environmentally compatible than the aging fleet replaced [13]. Caltrain is considering their purchase to complement planned electrification with $2 \times 25 \mathrm{KV}$ catenary to share track with the future CA HSR.

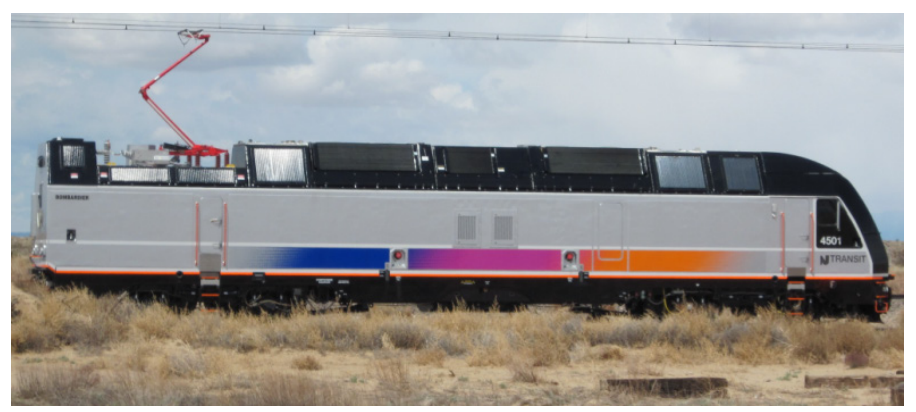

Figure 4. The new Bombardier ALP-45 DP dual powered (diesel and electric) hybrid locomotive now operated by New Jersey Transit commuter rail

At present, most light and heavy rail and electric commuter rail systems do not yet capture and reuse braking energy. Newer electric rail systems with regenerative braking capability (Amtrak Acela, international HSR, and some commuter light rail vehicles (LRVs) were able to save and reuse 10 to 20 percent of energy consumption. For commuter rail with frequent stops, regenerative braking is an attractive E2 option. Regenerative braking can be used to capture and reuse the electricity produced by dynamic braking. Dynamic braking runs the electric motor in reverse to slow the train, so that it acts like a generator producing electricity. Currently, most 
trains dissipate the dynamic braking energy by using banks of resistors located on top of locomotives that heat up in the process (called rheostatic braking). A cooling grill for the brake grid resistors is typically placed at the top of the locomotive. ECP (air) brakes are increasingly used, but energy savings can be realized only if all railcar brakes are connected. Regenerative braking requires an on-board, or a wayside Rechargeable Energy Storage System (RESS/WESS) to store and deliver on demand the recovered kinetic energy, which is typically wasted as frictional heat. The RESS or WESS can use advanced lithium-ion batteries, capacitors or flywheel technologies- alternatives currently being evaluated in service. The recovered braking energy can be returned to the Overhead Catenary System (OCS), the grid, or reused for other trains at peak load demand such as acceleration, or hill climbing. Examples include:

- The Los Angeles Metrolink commuter rail was funded in 2010 by an FTA Transit Investments in Greenhouse Gas and Energy Reduction (TIGGER) grant to deploy WESS [14] on the Red Line. Its Westlake Energy Storage System uses magnetically levitated flywheels to capture, store and release on-demand regenerated braking energy at the Westlake at-grade rail station.

- In 2010 South Eastern Pennsylvania Transit Authority (SEPTA)- an electrified commuter rail with regenerative braking capability - partnered on a WESS pilot with: Viridity Energy to optimize traction power substation (TPSS) energy storage for return and reuse to the grid; Saft to provide lithium ion batteries for trackside energy storage; Envitech to serve as WESS integrator and use its Vpower software for power quality; and ENVISTORE DC for the DC converter and power control system [15]. A 2011 TIGGER award to SEPTA deployed and evaluated WESS energy savings in an updated substation on the Market Frankford line. It uses advanced lithium ion batteries for energy storage and reuse at peak loading [16].

Another emerging commuter railroad strategy to improve E2 is to use lighter weight, but crashworthy locomotives. . In June 2012, FRA approved the first alternative design waiver [17] for the TX Denton County Transportation Authority to purchase and operate 11 new Stadler diesel-electric DMU lightweight unit cars (Figure 5). The DMUs will be used on the A-Train, serving a 21-mile $(34 \mathrm{~km})$ commuter rail line shared with freight trains, and linked to Dallas Area Rapid Transit (DART). These DMUs are also used on Austin's Capital Metrorail Red Line. The Stadler 2/6 (or larger 2/8) lightweight railcars are more fuel efficient by 30-70 percent, operate up to $75 \mathrm{mph}$ $(120 \mathrm{~km} / \mathrm{h})$ with less noise, yet feature a crash energy management (CEM) system to protect passengers in a crash [18].

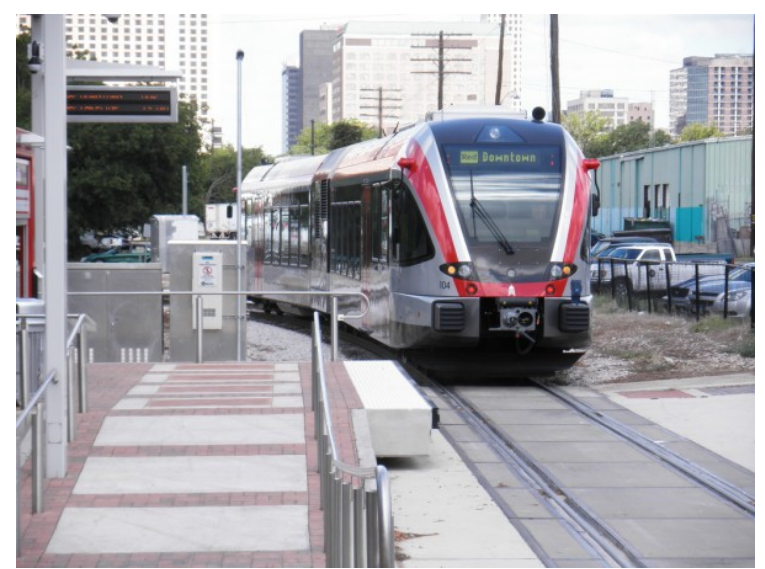

Figure 5. The Stadler 2/6 lighter weight DMU in Austin, TX waivered by FRA in 2013

\section{EXAMPLE OF E2 FREIGHT RAIL GAINS FROM INTEGRATING EQUIPMENT WITH LOGISTICS OPTIMIZATION TOOLS}

The GE Evolution series diesel electric locomotives used by Class I freight railroads can be integrated for better fuel efficiency with the GE Locotrol distributed-power controller and Trip Optimizer energy management software for operational optimization and engine control. Implementation of the full suite of GE Fuel Savings Solutions can improve locomotive efficiency by up to 15 percent. The Trip Optimizer [19] automated throttle controller adjusts the locomotive speed profile and minimizes braking, based on train length, weight, grade and track conditions, and weather. It has been implemented successfully on 200 Canadian Pacific (CP) freight locomotives since 2009 [20], achieving up to 6-10 percent annual fuel savings on certain routes. Trip Optimizer software improves fuel efficiency by only 1 percent for the average mainline locomotive, but this affords annual fuel savings of 32,000 gallons (121,600 liters), 365 tons $(328,500 \mathrm{~kg})$ of GHG, 5 tons $(4500 \mathrm{~kg}) \mathrm{NO}_{\mathrm{x}}$, and 0.2 tons $(180 \mathrm{~kg})$ of PM cuts. This software is also compatible with the GE LOCOTROL distributed power controller and the GE's RailEdge Trip Planner to secure further fuel savings of 3-15 percent, depending on the territory. 


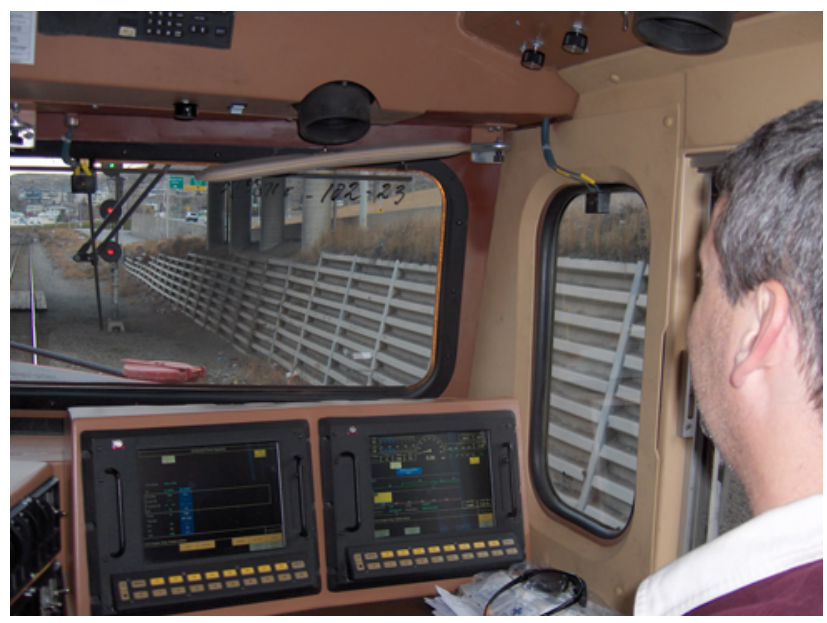

Figure 6. GE Trip Optimizer Software Used for Status Display in Locomotive Cab [21]

The GE Trip Optimizer (Figure 6) autocontrol tool can be coupled to other GPS tracking and scheduling software in the GE Evolution series of energy efficient and eco-friendly railroad products: auto-engine start-stop (AESS) automated Notch 8 Fuel Economy to adjust the power; the AccuFuel gage measuring fuel level for improved monitoring and management; and the engine Smart Burn optimizer to balance engine performance over the duty cycle [22]. Over 2000 US freight locomotives are equipped with the Trip Optimizer, including 1,300 on CSX locomotives [23].

Other energy use monitoring and idle reduction control devices are being implemented to improve E. The EPA SmartWay program [24] has certified retrofit kits for locomotive idle reduction that save fuel and reduce emissions in railyards in/near non-attainment or maintenance areas, e.g.:

- Shore Connection Systems (SCS) for railyard electrically powered heaters, to reduce switcher locomotive idling that keeps the engine warm and control HVAC in cabs during severe weather.

Auxiliary Power Units (APUs) and generator sets verified for effectiveness by EPA. For instance, CSXT formed EcoTrans Technologies in 2002, as a joint venture with International Road and Rail Inc., to market the K9 Auxiliary Power Unit (APU) used to reduce idling. In 2006, DOE/EERE [25] considered the EcoTrans K9 technologies to be a commercialization success story for energy efficiency technologies, with more than 3,600 units installed in locomotives, which improved E2 by up to 83 percent and cut emissions.

- Automatic Engine Stop Start (AESS) systems are available as retrofits to improve the performance of older locomotives [26]. AESS technologies require sophisticated control hardware and software for shutdown prevention and smooth locomotive restart in all weather. Some kits integrate the AESS with an APU for GE and EMD locomotives.

\section{EVALUATION OF ALTERNATIVE FUELS}

Use of renewable biodiesel (B20 blends) from various feedstocks illustrated in the report include Joint the FRA test and evaluation of biodiesel B20 emissions and performance by Amtrak in-service locomotives, with GE Transportation Services, Chevron-Oronite, and OK DOT in passenger service from Fort Worth, TX, to Oklahoma City, OK; evaluation of locomotive efficiency and emissions with positive results by Southwest Research Institute (SwRI); by BNSF in northern Montana; by the Coalition for Sustainable Rail (CSR)- a partnership between the University of Minnesota and Sustainable Rail International (SRI). NS also used biodiesel (both synthetic and from animal waste) to lower emissions at a fueling station and railyard in Meridian, MS with positive results, using more than 800,000 gallons (3 million liters) of biodiesel a month. In 2012, NS agreed to purchase diesel fuel produced by Dynamic Fuels, a 50/50 venture owned by Tyson Foods, Inc. and Syntroleum Corporation. The Iowa Interstate Railroad, a $500 \mathrm{mi}(800 \mathrm{~km})$ regional railroad, has also been using renewable biodiesel (blends of 10-20 percent), biodegradable soybean grease, to reduce wheel-track wear on curves. FRA's E3 program managers also participate in the SAE TC7 Subcommittee on Biodiesel in Railroad Applications, in the Committee on PRIIA Next Generation Equipment, and in the AASHTO/SCORT. .. In 2007 BNSF, AAR and UP jointly evaluated natural gas fueled locomotives. Currently, the FRA, AAR and Class I railroads are jointly testing and evaluating the efficiency and safety of LNG locomotives, such as the GE Evolution series NextFuel prototype, including an LNG tender car, for range assurance

\section{GENERAL FINDINGS AND RECOMMENDATIONS}

The report findings and recommendations for sustained E2 improvements were tailored to sector- specific needs and goals for improved, but cost-effective, E2 and environmental performance.

Key strategies and opportunities for continued E2 and environmental advances include participating in:

- Partnerships with Federal agencies to develop and evaluate advanced technologies, alternative locomotive fuels for Tier 4 compliance (EPA SmartWay, and Clean Diesel and DERA-funded grants);

- Partnerships with trade associations (AAR, APTA, AASHTO);

- Initiating multi-year joint RDT\&E initiatives and activities related to advanced locomotive traction and energy storage technologies, alternative fuels, and operations control optimization tools promising to reduce emissions while improving E2 performance;

- Joining in international rail organizations E3 initiatives (e.g., UIC) and/or Standards Developing Organizations (SDOs) to build industry consensus and facilitate the emergence of energy efficient rail technologies and fuels; 
- Partnering with regional and State environmental protection agencies for E2 and cross-enterprise sustainability improvements;

- $\quad$ Playing an active role in rail industry partnerships cofunded with Federal, State, and regional agencies to improve air quality and reduce energy consumption.

- Competing for E2 and E3 sustainability awards that recognize Best in Class rail industry achievements in energy efficiency, cross-enterprise sustainability commitments and initiatives, and related Climate Change mitigation efforts including:

○ adopting the APTA Sustainability Commitment,

$\circ$ the AAR Energy and Environment initiatives, or similar Climate Change mitigation BPs [27], such as Amtrak's annual posting of its Environmental report [28] and Climate Counts Scorecard, or the Norfolk Southern (NS) "Connections" sustainability report; Railroads will continue to gain E2/E3 benefits from developing and deploying promising technologies to achieve compliance with Tier 42015 EPA locomotive emission standards, including:

- On-board and wayside energy storage

- Capture and reuse of energy from engine exhaust

- $\quad$ Energy storage systems (onboard and wayside)

- Optimization of cylinder temperature and in-cylinder combustion

- Alternative fuels and blends thereof

- After-treatment Systems

- Synergistic combinations of technologies with software tools; and

- Weight Reduction

\section{ACKNOWLEDGMENTS}

The authors thank the Volpe project team (Joseph Sposato and Bernard Kennedy), as well as Suzanne Horton and Leonard Allen for project management oversight and guidance.

\section{REFERENCES}

[1] "Best Practices and Strategies for Improving Rail Energy Efficiency," 2014.

http://www.fra.dot.gov/eLib/details/L04922\#p3_z10_gD_1RT or http://ntl.bts.gov/lib/51000/51000/51097/DOT-VNTSCFRA-13-02.pdf[2]_NCRRP 02-01, Comparison of Passenger Rail Energy Consumption with Competing Modes, http://apps.trb.org/cmsfeed/TRBNetProjectDisplay.asp?ProjectI $\mathrm{D}=3482$

[3] CASE: Energy Efficiency and Reliability Solutions for Rail Operations/Facilities http://trid.trb.org/view.aspx?id=1316835[ 4] Railenergy and "Innovative Integrated Energy Efficiency Solutions for Railway Rolling Stock, Rail Infrastructure and Train Operation" at www.railenergy.org
[5] See for Tier 3+ or 4 locomotives from GE Transportation, Electro-Motive Diesel, Brookville Equipment Co., Wabtec MotivePower Division, R.J. Corman RailPower, Knoxville Locomotive Works, MTU, and Cummins

http://www.railwayage.com/index.php/mechanical/locomotives/ a-few-clean-breakthroughs.html

[6] "Freight Railroads Help Reduce Greenhouse Gas

Emissions," AAR April 2014 at

https://www.aar.org/keyissues/Documents/BackgroundPapers/Freight $\% 20$ RR $\% 20$ Help $\% 20$ Reduce $\% 20$ Emissions.pdf [7] "The environmental benefits of moving freight by rail", AAR April 2014 at

https://www.aar.org/keyissues/Documents/BackgroundPapers/Environ $\% 20$ Benefits $\% 20$ of $\% 20$ Moving $\% 20$ Freight $\% 20$ by $\% 20$ Rail.pdf

[8] CARB Railyard Emission Reduction Program postings at http://www.arb.ca.gov/railyard/railyard.htm.; and 2007 AAR, BNSF and UP study at

http://www.arb.ca.gov/railyard/ryagreement/112807lngqa.pdf

[9] Photographs (C) Tim Hurst

[10] See http://www.industrytap.com/ges-hybrid-locomotivemoves-a-ton-of-freight-500-miles-on-a-gallon-of-fuel/4226

[11] http://www.amtrak.com/travel-green-with-amtrak and "Amtrak Means Energy Efficiency" at

http://www.amtrak.com/servlet/ContentServer?c=AM_Content

C\&pagename $=$ am $\% 2$ FLayout\&cid $=1241245661727$

[12] Image courtesy of Siemens

[13] See

http://www.railwaygazette.com/news/passenger/singleview/view/new-jersey-transit-unveils-first-alp-45-loco.html [14] See WESS and other E2 technologies in "Greenhouse Gas Emissions Cost Effectiveness Study" by ICF for LACMTA, $2010 \quad$ posted at http://media.metro.net/projects_studies/sustainability/images/G HGCE 2010 0818.pdf

[15]See details of SEPTA WESS project at http://www.septa.org/sustain/pdf/viridity-faq.pdf

[16]See SEPTA Sustainability blogs postings at http://www.septa.org/sustain/blog/2011/07-15.html and http://www.septa.org/sustain/blog/2011/11-23.html

[17]See "Commuter Rail Lightens Up" in ASCE Civil Engineering Magazine at http://www.asce.org/CEMagazine/Articlens.aspx?id=25769811 $\underline{158}$

[18]See http://www.pddnet.com/articles/2014/07/improvingcrashworthiness-railcars

[19] See Oct. 2010 www.railwayage.com/breaking-news/getransportation-touts-trip-optimizer.html [ERROR MESSAGE]

[20] See "GE fuel autopilot software set for 200 locomotives," July 2009, at www.gereports.com/category/ecoimagination/ [ERROR MESSAGE]

[21]Source: http://www.gereports.com/ges-fuel-autopilotsoftware-set-for-200-locomotives/;__photograph courtesy General Electric Company 
[22]See GE Fuel Saving Solutions brochure at www.getransportation.com/

[23]"Trip Optimizer: Autocontrol System Saves Fuel", TR News May-June 2013, p 50 at http://www.trb.org/Main/Blurbs/169265.aspx

[24]See idle reduction technologies at www.epa.gov/smartway/technology/idling.htm

[25]See "Auxiliary Power Unit Cuts Emissions, Fuel Use in Locomotives"

http://www1.eere.energy.gov/vehiclesandfuels/pdfs/success/loc omotive apu.pdf.

[26]See Mechanical Equipment for the Eco-Minded," March 2009 article in Progressive Railroading.
[27]See "North American Industry Perspective on Sustainability", Feb.2013, $12^{\text {th }}$ Annual New Partners for Smart Growth Conference, by R. Fronczak, AAAR, Asst. V.P. Environment and Hazmat Association, at http://newpartners.org/2013/presentations/Saturday/1.45$3.15 \mathrm{pm} /$ Saturday $\% 209$ th $\% 20 \% 20 \% 20 \% 20 \% 20 \% 20 \% 201.45-$ $3.15 \mathrm{pm} \% 20 \% 20 \% 20$ Freight $\% 20$ Rail/NP13_Fronczak.pdf [28]See Amtrak 2012 Environmental Report at http://www.amtrak.com/ccurl/883/945/Amtrak\%202012\%20En vironment $\% 20$ and $\% 20$ Sustainability $\% 20$ Summary Final.pdf 